\title{
Methods explained
}

Methods explained is a quarterly series of short articles explaining statistical issues and methodologies relevant to ONS and other data. As well as defining the topic areas, the notes explain why and how these methodologies are used. Where relevant, the reader is also pointed to further sources of information.

\section{The GDP implied deflator}

\author{
Anis Chowdhury
}

\section{Office for National Statistics}

\section{SUMMARY}

This article will introduce readers to the concept of the gross domestic product (GDP) implied price deflator. The GDP implied deflator is used to measure changes in the overall level of prices for the goods and services that make up GDP. It is an important indicator in the National Accounts as it distinguishes output growth that comes about due to volume increase and that due to price changes. In effect, the GDP implied deflator illustrates how much of the change in nominal GDP from one year to another reflects changes in the price level. It is referred to as the implied deflator: for example, if GDP increases by 2 per cent in real terms and 5 per cent in nominal terms, the implied economy-wide rate of inflation is 3 per cent.

wo different measurements are used to calculate the gross domestic product (GDP) growth rate attributable to volume and price changes:

- current (nominal) GDP - measures value of transactions in the prices relating to the period being measured and is both a volume and price indicator, and

- constant (real) GDP - measures relative changes in the volume of goods and services between one period and another

The ratio of the current to constant price series is a measure of price movements, and this forms the basis for the calculation of the implied GDP deflator.
The GDP of a country can be measured in three ways: the output, expenditure and income approach. It is defined as the total market value of all final goods and services produced within a country in a given period of time. ${ }^{1}$

So, why is the distinction between output growth from changes in volume and changes in prices important? If output growth is due to an increase in prices, but volumes have remained the same, then changes in GDP are not due to economic growth. By taking away the price effects of output growth, that is, by deflating, one can obtain the 'real' measure of GDP growth. This central economic issue can be illustrated in the simple example in Box 1. For simplicity's sake, a closed economy is one that is assumed to produce just two goods, clothes and food.

As illustrated in the worked example, it is difficult to see how much the growth rate in GDP has come about due to changes in the volume of output or price. This has obvious implications for measuring growth from one year to the next, as it means that changes in GDP may not necessarily mean that the economy is growing. If, for example, in year three, the price of clothes increases to $£ 3$ and the quantities produced remain the same from year two, the GDP growth rate in overall nominal terms will show a 41 per cent increase. While the market value of the goods and services produced by the country has increased, the volume of goods and services produced has not.

This methodology article will go on to show how the GDP deflator is

Box 1

Simple growth rate calculation

\begin{tabular}{|c|c|c|c|c|}
\hline Year & Price of clothes & Quantity of clothes & Price of food & Quantity of food \\
\hline 1 & $\mathrm{f} 1.00$ & 50 & f3.00 & 300 \\
\hline 2 & $£ 2.00$ & 100 & $£ 3.00$ & 500 \\
\hline 3 & $£ 3.00$ & 100 & $£ 3.00$ & 700 \\
\hline
\end{tabular}

GDP is simply the sum of $P$ (price) times $Q$ (quantity), with i being the particular product. For example:

$\sum P_{i} Q_{i}=G D P(f 1 \times 50)+(£ 3 \times 300)=£ 950=(G D P)$

To calculate the nominal GDP growth rate, GDP for the second year is divided by GDP for the first year, and then one is subtracted as follows then multiplied by hundred. For example, in this case, the GDP growth rate from year one to year two would be 79 per cent in nominal terms:

GDP growth rate $=\frac{\left[\mathrm{GDP}_{2}\right]}{\left[\mathrm{GDP}_{1}\right]}-1 \times 100$ i.e. $\frac{1700}{950}-1 \times 100=79 \%$ 
calculated; explain briefly volume derivation; explain how the GDP deflator compares with the retail prices index - all items excluding mortgage interest payments (RPIX); and finally how the GDP deflator will be related to recent UK experience.

\section{The construction of the GDP implied deflator}

This section will illustrate how the GDP implied deflator is derived using a basic equation. It will then develop this to show how, using a simple example, the Office for National Statistics (ONS) obtains its current and constant price volume measures and deflator.

The basic equation for deriving the GDP deflator is shown below:

GDP implied deflator $=\frac{\text { current price }(\mathrm{CP})}{\text { constant prices }(\mathrm{KP}) \text { volume }}$

$\mathrm{x} 100$

The implied GDP deflator is simply the current price divided by the constant price volume measure.

ONS uses the Laspeyres index to obtain the constant price volume of growth and is represented by the following equation, where $\mathrm{P}$ denotes price and $\mathrm{Q}$ quantity, $\mathrm{P}_{0}$ and $\mathrm{Q}_{1}$ relates to current prices and quantity in year one and $\mathrm{P}_{0} \mathrm{Q}_{0}$ is the summation of volume in year two at base prices:

\section{$\sum \mathrm{P}_{0} \mathrm{Q}_{1}$ \\ $\overline{\mathrm{L}}=\sum \mathrm{P}_{0} \mathrm{Q}_{0}$}

The Laspeyres index is used to calculate volume growth between two periods; it compares the sum of goods and services in the first (or base) period, weighted by a given price structure, with the sum of the physical units in the second period, weighted by the same price structure. This in effect takes out the variation in prices between the two periods, thus capturing purely the volume effect. This is then chain linked (see Robjohns 2006).
The derivation of the GDP implied deflator can be illustrated using the simple example in Box 2.

\section{Derivation of volume measures}

The derivation of volume measures can be either market or nonmarket based: market-based volume measures are a form of direct deflation. Price indices, such as the producer price indices or the consumer price indices, are primarily used in deflating consumption expenditure, that is, food and services. Non-market output (output that is provided free) applies in situations where price measurement does not seem possible or feasible. This can be divided into two types:

- individual goods and services - those that are consumed by households such as on education and health, and

- collective services - where services are provided to society as a whole, for example, public administration and defence

For both these categories, output is hard to define. With regard to collective services, there is no transaction between producer and consumer. Without prices for the output, there are only two options for constant price measurement: deflating inputs, and direct volume measurement. Measuring prices and volumes for non-market output at current prices is defined as the sum of costs minus revenues. In an input method, the output in constant unit costs is approximated by deflating the current year costs or extrapolating base-year costs.

\section{The GDP implied deflator versus the retail prices index}

The implied GDP deflator and the retail prices index (RPIX) are both measures of inflation. However, there are differences, with the main ones highlighted in Box 3.

\section{Box 2}

\section{Deriving the GDP implied deflator using the Laspeyres chained volume index}

\begin{tabular}{|c|c|c|c|}
\hline & A & B & c \\
\hline 1 & & \multicolumn{2}{|c|}{ Year } \\
\hline 2 & & 0 & 1 \\
\hline 3 & Prices & & \\
\hline 4 & Good 1 & 50 & 60 \\
\hline 5 & Good 2 & 40 & 50 \\
\hline 6 & Quantities & & \\
\hline 7 & Good 1 & 100 & 200 \\
\hline 8 & Good 2 & 200 & 300 \\
\hline 9 & Nominal GDP & 13,000 & 27,000 \\
\hline 10 & Index at nominal prices & & 208 \\
\hline 11 & Real growth rate of output (Laspeyres index) (previous year's prices used as weights) i.e. $\sum \mathrm{P}_{0} \mathrm{Q}_{1}$ & 13,000 & 22,000 \\
\hline 12 & Laspeyres volume index & & 169 \\
\hline 13 & Volume index obtained by deflation & & 123 \\
\hline
\end{tabular}

First sum $50 \times 100(B 4 \times B 7)+40 \times 200(B 5 \times B 8)=13,000$ (B9). Then sum $60 \times 200(C 4 \times C 7)+50 \times 300(C 5 \times C 8)=27,000$ (C9). Dividing 27,000 by 13,000 (C9/B9) $\times 100$, the current price index of 208 is obtained.

To calculate the Laspeyres index, $\sum \mathrm{P}_{0} \mathrm{Q}_{0}$ is first derived, which relates to the current prices for year zero, that is, 13,000 . The current volumes for year one at year zero prices is $\sum \mathrm{P}_{0} \mathrm{Q}_{1}, 200 \times 50+300 \times 40=22,000$. The volume index is calculated between the two periods by dividing 22,000 by 13,000 (C11/ B11) $\mathrm{x}$ $100=169($ C12).

To obtain the deflator, the current price index is divided by the Laspeyres volume index - divide 208 by $169(\mathrm{C} 10 / \mathrm{C} 12) \times 100=\mathrm{GDP}$ implied deflator $=123$ (C13), so prices have risen by 23 per cent. 
Box 3

Comparison between the GDP implied deflator and RPIX

\begin{tabular}{lll}
\hline Differences & GDP implied deflator & RPIX \\
\hline Measures & $\begin{array}{l}\text { Indirect measure of inflation - derived from sub-components of the } \\
\text { National Accounts that are either deflated at a low level with a few } \\
\text { (in particular government) based on direct measures of output then aggregated. }\end{array}$ & $\begin{array}{l}\text { Direct measure of inflation - compiled from the prices of goods and } \\
\text { services provided by businesses to households. Measures consumer prices. }\end{array}$ \\
Coverage & $\begin{array}{l}\text { Is a broad measure of inflation. The GDP deflator reflects price movements in all } \\
\text { aspects of the economy including household spending, government spending, } \\
\text { investment and net trade. It is a weighted average of these price effects including } \\
\text { negative weights for imports. }\end{array}$ & Applies to goods and services consumed by households. \\
Weighting & $\begin{array}{l}\text { Is current weighted, reflecting changes in prices and expenditure weights, that } \\
\text { is, current spending patterns. Since the weights reflect the composition of GDP }\end{array}$ & Compares the prices of a constant basket of goods and services between \\
& in each period, changes in the index reflect movements in both prices andthe & any two periods. Is base weighted. \\
& composition of GDP.
\end{tabular}

Figure 1

\section{Comparison in growth rates between the GDP} deflator and RPIX

Percentage change, quarter on quarter

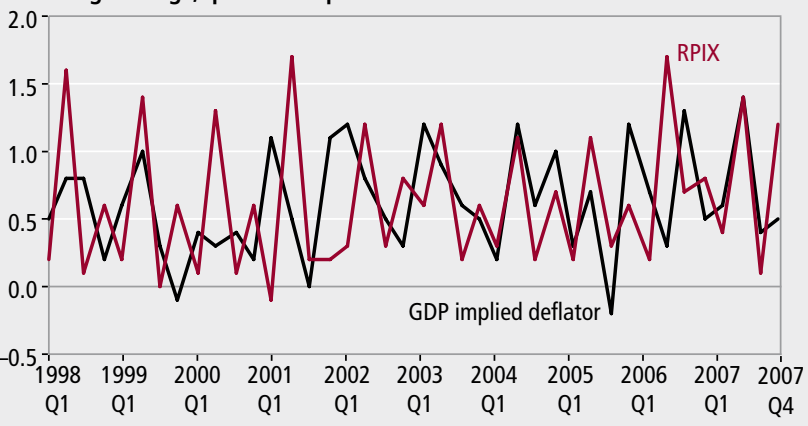

In principle, there should be little difference between the GDP deflator and RPIX, as both measure average changes in prices.

Figure 1 shows that, empirically, the GDP deflator and RPIX tend to exhibit similar trends. Any differences between the GDP deflator and the RPIX can largely be accounted for by price movements in goods and services traded abroad and government output.

\section{The recent UK experience}

Column A in Table 1 shows the money value of UK economic output (GDP) which reflects changes in both output and prices. The next two columns disentangle these factors. Column B shows the volume of output with all goods and services measured in 2003 prices and by definition are equal to GDP at current prices. Column $\mathrm{C}$ indicates the path of inflation, that is, the deflator.

Figure 2 gives a time series graphical presentation of the UK

Table 1

Current, constant and deflator index series

\begin{tabular}{|c|c|c|c|c|c|}
\hline & $\begin{array}{r}\text { Current prices } \\
(\mathrm{f} \text { million) }\end{array}$ & $\begin{array}{r}\text { Constant prices } \\
(\mathrm{f} \text { million })\end{array}$ & $\begin{array}{r}\text { Price deflator } \\
\text { index }(2003=100)\end{array}$ & $\begin{array}{r}\text { Current prices } \\
\text { index }(2003=100)\end{array}$ & $\begin{array}{r}\text { Constant prices } \\
\text { index }(2003=100)\end{array}$ \\
\hline & A & B & C & D & $E$ \\
\hline 1987 & 421,559 & 757,452 & 55.7 & 37.7 & 67.7 \\
\hline 1988 & 470,748 & 795,317 & 59.2 & 42.1 & 71.1 \\
\hline 1989 & 517,075 & 812,725 & 63.6 & 46.2 & 72.7 \\
\hline 1990 & 560,887 & 819,007 & 68.5 & 50.2 & 73.2 \\
\hline 1991 & 589,739 & 807,814 & 73.0 & 52.7 & 72.2 \\
\hline 1992 & 614,776 & 809,540 & 75.9 & 55.0 & 72.4 \\
\hline 1993 & 645,500 & 827,886 & 78.0 & 57.7 & 74.0 \\
\hline 1994 & 684,067 & 863,623 & 79.2 & 61.2 & 77.2 \\
\hline 1995 & 723,080 & 889,041 & 81.3 & 64.7 & 79.5 \\
\hline 1996 & 768,905 & 913,800 & 84.1 & 68.8 & 81.7 \\
\hline 1997 & 815,881 & 942,154 & 86.6 & 73.0 & 84.3 \\
\hline 1998 & 865,710 & 973,748 & 88.9 & 77.4 & 87.1 \\
\hline 1999 & 911,945 & $1,003,370$ & 90.9 & 81.6 & 89.7 \\
\hline 2000 & 958,931 & $1,041,517$ & 92.1 & 85.8 & 93.1 \\
\hline 2001 & $1,003,297$ & $1,066,217$ & 94.1 & 89.7 & 95.3 \\
\hline 2002 & $1,055,793$ & $1,088,108$ & 97.0 & 94.4 & 97.3 \\
\hline 2003 & $1,118,245$ & $1,118,245$ & 100.0 & 100.0 & 100.0 \\
\hline 2004 & $1,184,296$ & $1,154,685$ & 102.6 & 105.9 & 103.3 \\
\hline 2005 & $1,233,976$ & $1,175,916$ & 104.9 & 110.3 & 105.2 \\
\hline 2006 & $1,303,915$ & $1,210,288$ & 107.7 & 116.6 & 108.2 \\
\hline 2007 & $1,384,823$ & $1,246,895$ & 111.1 & 123.8 & 111.5 \\
\hline
\end{tabular}

Source: Office for National Statistics 
current and volume price series data. The GDP implied deflator can be simply inferred as the relative gap between the two. It can be deduced from the graph that:

- nominal GDP has risen in every year since 1987

- the deflator has also risen in every year since 1987, and

- constant price GDP has increased in every year since 1987, except between 1990 and 1991

Table 1 shows that the value of output rose between 1990 and 1991 (from $£ 560.9$ billion to $£ 589.7$ billion), although at prices ruling in 1990 , real output fell over the same period (from $£ 819.0$ billion to $£ 807.8$ billion) - referenced to 2003 base year prices.

\section{Figure 2}

\section{UK GDP inflation experience}

$\mathrm{f}$ billion

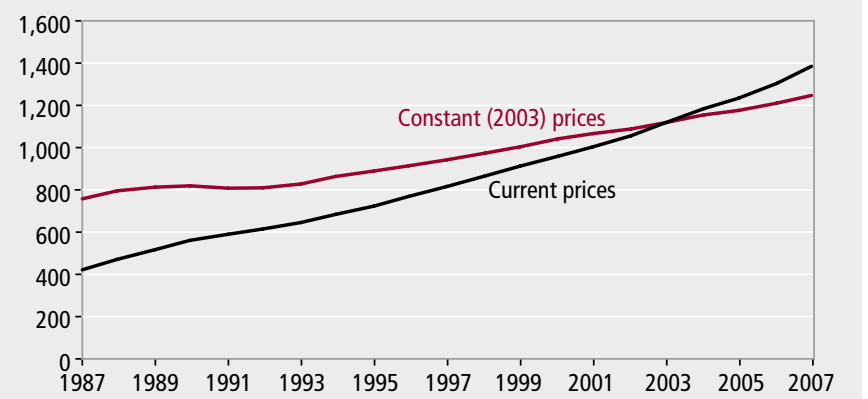

\section{Notes}

1 The standard definition is enshrined in the international reference manual, the System of National Accounts 1993 (SNA 93), where GDP is defined as 'the sum of the gross values added of all resident producers at basic prices, plus all taxes less subsidies on products'.

\section{CONTACT}

龱elmr@ons.gsi.gov.uk

\section{REFERENCES}

Eurostat: Handbook on price and volume measures in national accounts.

Lequiller F and Blades D (2006) 'Understanding National Accounts'. Office for National Statistics (2007) UK National Accounts: The Blue Book 2007.

Robjohns J (2006) 'Annual chain-linking', Economic Trends 630, pp 25-8. 